\title{
Performance Management in Insurance Firms by Using Transfer Pricing
}

\author{
René Doff \\ Jan Bilderbeek \\ Bert Bruggink \\ Pieter Emmen
}

\begin{abstract}
In this article, we analyze the asset and liability management and market risk systems of insurance companies. We discuss that the current system is not goal congruent and does not satisfy necessary conditions for effective control. It follows that managers are unable to run their business effectively. We develop a transfer pricing system that allows the clear separation of underwriting and investment activities, both on the risk and return aspects. It creates the appropriate incentive schemes. We illustrate this system with an example indicating the differences in incentives between the traditional embedded value measures and the proposed funds transfer pricing system.
\end{abstract}

\section{INTRODUCTION}

Adequate risk management requires a system for effective management control based on the risk profile. In this article, we analyze the system that is currently in place in insurance firms to monitor asset and liability management (ALM) and market risks. We argue that because insurance firms cannot separate risk and result components, the current system does not satisfy the necessary conditions for effective management control (second section). Therefore, we adjust the so-called funds transfer pricing system that is used in banking (third section) so that it can be implemented in insurance firms (fourth section). Based on our experience, only a few insurance firms apply such a system for effective management control. We conclude with a practical example (fifth section) indicating the differences in incentives between the traditional embedded value measures and the proposed funds transfer pricing system.

René Doff is with Eureko, the largest insurance group in the Netherlands and chaired the Dutch Solvency II Working Group; phone: +31-53-4893510; fax: +31-53-4892159; e-mail: rene.doff@gmail.com. Jan Bilderbeek is Professor of Financial Management and Accounting at the University of Twente, the Netherlands; phone: +31-53-4893510; fax: +31-53-4892159. Bert Bruggink is Professor of Financial Institutions and Markets at the University of Twente, the Netherlands; phone: +31-53-4893510; fax: +31-53-4892159. In addition, he is the Chief Financial Officer, Rabobank Group, one of the largest Dutch banking groups. Pieter Emmen is Chief Risk Officer of the Rabobank Group. This article was subject to double-blind peer review. The authors are grateful for comments from anonymous reviewers. 


\section{Asset and Liability Risks and Management Control}

To manage and measure market risks, insurance firms generally apply ALM (Doff, 2007; Booth, 1999). Smink (1995) distinguishes macro-ALM and micro-ALM. Macro-ALM consists of the strategic choices regarding the product portfolio, capital structure, and the risk profile/appetite of the firm. It includes three elements: (1) investment policy, that is, micro-ALM (see below); (2) actuarial policy, that is, the evaluation process of underwriting variables like claims and mortality; and (3) premium policy, that is, determining how much of the investment income is allocated back to the policyholders. Micro-ALM (also called matching) is the choice of investment tactics to hedge the financial risks of a given liability structure (also see: Van der Aalst, 1995; KPMG, 2002).

Management control is the process by which managers influence other members of the organization to implement the organization's strategy (Anthony, 1988). In organizations, incentives must be created so that the objectives of agents and principals are aligned. Anthony and Govindarajan (2003) state: "The central purpose of a management control system is to ensure ... goal congruence. In a goal congruent process the actions people are led to take in accordance with their perceived self-interest are also in the best interest of the organisation." One way to achieve goal congruence is to link rewards to the performance of the agent. Performance measures are essential components of management control. We will argue below that currently underwriting managers' performance measures are not always goal congruent.

De Leeuw (1990) defines the conditions for effective control (Pape, 1999):

1. There must be an objective/goal; otherwise goal-directed influence is not possible.

2. A model of the controlled unit must be available, such that the controlling entity can predict the effect of its control.

3. Information on the state of the controlled unit and the environment must be available, such that the controlling entity knows which controlling measure to choose.

4. Sufficient measures should be available to react to disruptions. The variety of controlling measures should be at least as large as the variety of disruptions (law of requisite variety).

5. The controlling entity should have sufficient information capacity to transform new information into an effective control measure/action.

Insurers have started to identify the weaknesses in their current performance management systems and are increasingly using risk- and value-based performance measures using stochastic models (Comité Européen des Assurances (CEA), 2007; Klumpes, 2005; Liebenberg and Hoyt, 2003; Santomero and Babbel, 1997). Most dominantly, embedded value in the life insurance industry is used as management control tool. While embedded value should be considered an important step forward from the traditional profit-based performance measures, it is still far from ideal because investment results and underwriting results are evaluated integrally whereas separate results information is necessary. To solve the problem of joint results information, we propose applying the funds transfer pricing system in the fourth section. 
The concept of the funds transfer pricing system developed in the fourth section bears important similarities with the replicating portfolio principle (Rubinstein, 2001; Broadie et al., 1998). However, the replicating portfolio principle is often used as an input for the micro-ALM strategy only. Below, we argue that it is important to extend the results to performance measures and macro-ALM to promote goal-congruent behavior for both the investment and the underwriting centres. By using the appropriate performance measures, the proposed funds transfer pricing system stimulates the underwriting centre to address investment consequences of the underwriting activities in advance. In addition, the funds transfer pricing system impacts all macro-ALM components and not only the investment policy. As a result, it promotes goal-congruent behavior better.

From a management control perspective, two questions should be answered when analyzing performance

\section{Did underwriting variables develop according to expectation?}

2. Did investment variables develop according to expectation?

The controller ${ }^{1}$ of an insurance firm answers these questions integrally. That is, he/she cannot address these questions separately, either in a profit-based or in an embedded value-based system. As a result, the underwriting department lacks incentives to improve poor underwriting results when investment results are good and vice versa. The reverse holds for the investment department.

However, the controller should answer the two questions separately for three reasons. First, instruments to alter the performance are different. Underwriting results can be improved by pricing and reinsurance decisions whereas investment results can be improved by asset allocation and (de)hedging decisions. Second, an integral perspective fails to have a steering function because there is no "alarm bell" for one unit if incidentally the other unit performs well. In a situation of goal congruence, both units aim to perform well independently from each other. Third, there is no two-way relation between the investment policy and the actuarial and premium policies. Mostly, the investment policy "follows" the actuarial and premium policies, but there is no feedback loop. As a consequence, an underwriting department can sell unhedgeable embedded options without properly charging the client for it. This is what happened during the 1990s in many countries (Mercer Oliver Wyman (MOW), 2004). The investment department seems to be "responsible" if interest rate developments result in an unhedged in-the-money embedded option.

Concluding, we identify the following problems in insurance with respect to ALM. The current situation does not satisfy the necessary conditions for effective control (de Leeuw, 1990) and does not enhance goal-congruent behavior (Anthony and Govindarajan, 2003). The problems are:

\footnotetext{
${ }^{1}$ We use the term controller/risk manager interchangeably because we believe that the combined efforts of these functions form an adequate management control system.
} 
1. Management has an inadequate model and inadequate information of an insurance policy as performance and risk are measured integrally (violation of conditions 2 and 3).

2. The insurance unit lacks the appropriate instruments to influence effects of all value changes of investments. This includes value changes due to credit spread and default as well as embedded optionalities (violation of condition 4).

3. The insurance unit has no incentives to design products that can easily be matched on the financial markets. There is no feedback from the investment units to the insurance units.

4. The insurance unit has no incentives that limit granting free embedded options, which are costly for the investment unit and as a result for the organization as a whole.

5. The investment centre is incentivized by the underwriting centre (rather than management) to invest in more risky securities when the latter wants to set a lower premium.

The next section evaluates the method with which banks resolved similar problems. The fourth section discusses the application to insurance firms.

\section{The Funds Transfer Pricing System in Banking}

A similar matching issue exists in banking. A bank's business model is built upon the transformation of the maturity- and liquidity-specific character of funds (Allen and Santomero, 1999; Schierenbeck, 2003; Gorton and Winton, 2002). The transformation function raises the issue on how to allocate the interest rate margin and consequently interest rate risk (Kimball, 1997; Kafafian, 2001). Schierenbeck (2003) develops the socalled "Marktzinsmethode." This is an example of the funds transfer pricing system in which the contract rate of a transaction is compared with a transaction with equivalent maturity characteristics (both maturity-specific and liquidity-specific characteristics) on the interbank market.

Exhibit: Example of Funds Transfer Pricing. Consider a bank issuing a 10-year mortgage of $€ 100,000$ at 6 percent, funded with a $€ 100,000$ savings deposit at 3 percent. Combined, these two transactions are quite profitable: the interest rate margin is 3 percent, that is, $€ 3,000$. How should we allocate the profit to the two products? For both products, the profitability is determined by comparing the contract rate with its interbank equivalent, the opportunity costs. The total result $(€ 3,000)$ is separated into three components: a commercial margin on the mortgage $(€ 1,000)$, a commercial margin on the savings deposit $(€ 500)$, and a transformation result $(€ 1,500)$. Figure 1 is a graphical representation.

A central component of the funds transfer pricing system is the transfer price (Chittenden, 2000). In the opportunity cost perspective, the performance of a unit must reflect the additional return compared to other opportunities (Schierenbeck, 2003). As interbank opportunities are widely available for the bank, it is common to take the interbank rates as transfer prices, or more precisely, matched-fund transfer prices (Payant, 2000). 


\section{FIGURE 1}

Funds Transfer Pricing System Splits Banking Result Components

\section{Element of Exhibit}

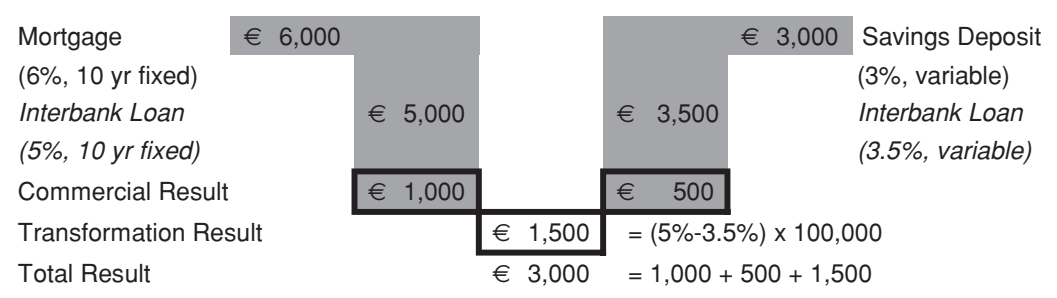

This transfer pricing schedule ensures goal-congruent behavior of commercial units (Kafafian, 2001).

The funds transfer pricing system resolves the allocation of the mismatch results by separating the mismatch and the two components of commercial results (Schierenbeck, 2003). Although it is originally developed to allocate results, it also separates the risks. Hence, it makes the banking business more controllable. Each risk component is separated to a level that it can be separately steered by a responsibility centre. Schierenbeck (2003) states that from the controlling perspective, the funds transfer pricing system is fair on the aspect of causality as well as performance because business units can influence their contribution only through means of setting better rates than the market equivalent (i.e., transfer price).

\section{Application of the funds Transfer Pricing System to Insurance}

In this section, we investigate how to implement the funds transfer pricing system in the context of insurance, satisfying the following criteria:

1. Performance (risk and return) should be measured uniquely; that is, any interference between different risks should be avoided.

2. Performance (risk and return) should be allocated to the unit that drives/causes the risk.

3. The unit that the risk is allocated to should have instruments available to manage the risk.

\section{The Concept}

In the second section, we introduced underwriting results and investment results. Accordingly, we define two responsibility centers: the underwriting centre and the investment centre. The underwriting centre is responsible for selling insurance policies for a fair actuarial price. Such a fair price (Babbel et al., 2002) takes into account underwriting risks only. The underwriting variables are evaluated on a best-estimate basis rather than on the traditional prudent basis. The underwriting centre invests its liabilities internally in the investment centre. As a result, the underwriting centre is perfectly matched. 


\section{TABLE 1}

Objective and Performance Measures Using the Funds Transfer Pricing System in Insurance

\begin{tabular}{lll}
\hline & \multicolumn{1}{c}{ Underwriting Centre } & \multicolumn{1}{c}{ Investment Centre } \\
\hline Objective & Managing underwriting position by & Managing mismatch position and \\
& selling insurance policies & capital base by investing in asset \\
& & portfolio \\
Performance & Added underwriting fair value & Fair value investment returns \\
Risks & Underwriting risk, unhegdeable & Market risks (predominantly interest \\
& embedded options & rate risk) and credit risk \\
RAROC & $\frac{\text { Added underwriting fair value }}{\text { Economic capital }}$ & $\frac{\text { Added investment fair value }}{\text { Economic capital }}$ \\
\hline
\end{tabular}

Investment risks are transferred through internal transactions to the investment centre, responsible for the assets and the mismatch. The internal transfer price excludes investment risks. Investment returns are generated from taking investment risks and managing the mismatch only. In addition to managing the mismatch position, the investment centre manages the so-called free assets (Booth, 1999) that cover the (equity) capital base of the insurance firm in excess of the insurance liabilities. Table 1 depicts this situation.

While the banking version of the funds transfer pricing system identifies three responsibility centers (lending, deposit taking, and treasury), the insurance version identifies two responsibility centers. This is because the mismatch of banking in itself is profitable. Hence, in banking there are three separately identifiable return drivers. Clearly, that is not the case for insurance. The mismatch of an insurance firm arises because some assets are nonexistent and because it is profitable to invest part of the assets in non-risk-free securities. Hence, in insurance there are only two return drivers as identified above.

\section{The Transfer Price}

An important element in this concept is the internal transfer price (cf. AMIfs Research Committee, 2001). The transfer price should clearly separate the underwriting and the investment centre (Harris and Raviv, 2005). It should stimulate goal-congruent behavior, partly by applying fair value (Calandro and Lane, 2004), both for the underwriting and for the investment centre. Also, the transfer price should avoid suboptimal behavior of both centers.

Anthony et al. (1992) argue that "... transfer pricing is not primarily an accounting tool. Rather it is a behavioral tool that motivates managers to take the right decisions." To provide the right incentives, it is important that the underwriting centre bears no investment risk. Therefore, the internal transfer price should be risk free, that is, government bond rates or interbank swap rates (for those maturities for which government bonds are unavailable). This makes the system consistent with the applications in banking. A practical difference between the banking and insurance application is the focus on liquidity in banking. Normally, insurance liabilities are less liquid than banks' on demand deposits. Hence, the insurance funds transfer price focuses on interest rate maturities 
only. By taking the risk-free rate as the internal transfer price, we decompose the total risk into two mutually exclusive parts: the investment risk and the underwriting risk.

The transfer price based on risk-free rates for internal transactions fulfils the goalcongruence criterion because it clearly demarcates the difference between risk-free and risky investment of the liabilities. Hence, such a transfer pricing system satisfies Anthony et al.'s (1992) criteria for effective use of transfer pricing.

Taking the risk-free rate as transfer price assumes absence of systematic risk for underwriting risks. For the underwriting risks, this is a reasonable assumption because underwriting risks can be mostly diversified away by pooling (e.g., in one portfolio or by means of reinsurance contracts). Some underwriting risks may be less well diversifiable and hence include systematic risks, such as catastrophic event risks (e.g., pandemics, flooding). These risks should be incorporated in the fair value of liabilities including a separate market value margin, reflecting unhedgeable risks (International Actuarial Association (IAA, 2007; CEA, 2005; Federal Office of Private Insurance, FOPI, 2006). Hence, also for these liabilities the risk-free rate is used as funds transfer price. For the shareholder-interested in the risk and return of the insurance company as a whole-compensation of the systematic risks is addressed in the sum of fair value profit of underwriting and investment centres.

\section{The Underwriting Centre}

The objective of the underwriting centre is to maximize fair value by managing the underwriting position of the total insurance firm. The fair value (International Accounting Standards Board, 2004) of an insurance policy is the net present value of the expected cash flows discounted by the risk-free rate and based on best-estimate expectations of the underwriting variables. A market value margin is added to reflect unhedgeable risks. When selling an insurance policy, the underwriting centre must assess all actuarial expectations to derive the expected cash flow pattern. It invests this expected pattern internally in a series of risk-free bonds. This encourages the fair pricing of insurance policies and adequately captures the time effect of the liabilities. In addition, embedded options such as guaranties must be hedged internally as well. This forces the underwriting centre to identify and quantify embedded derivatives and avoids the writing of free guarantees or other embedded options without the sellers of the policies being charged for it. In the framework of responsibility accounting, the underwriting centre should bear the cost of such embedded options. Because liabilities are invested internally at the product level, performance may be assessed at product level as well.

However, some embedded options like lapse options and combined guaranties are not hedgeable with financial instruments. Therefore, they cannot be hedged via internal transactions. These embedded options remain in the book of the underwriting centre. By explicitly identifying them, the underwriting centre is encouraged to adequately price and manage these embedded options.

The performance of the underwriting centre is the added fair underwriting value during a particular period. For existing business, the created fair value may change due to changing expectations in the underwriting variables. When underwriting variables' expectations are stable, the performance of existing business equals exactly the riskfree rate. This value is created because the underwriting centre has gone through an 
additional period and the discounted future cash flows are discounted by one period less. Additionally, the underwriting centre realizes the budgeted market value margin in this period as a compensation for bearing the underwriting risks.

The risk of the underwriting centre is due to outcomes of the underwriting variables compared to actuarial expectations. As is increasingly common in the insurance industry, economic capital is the central risk measure (Zaik et al., 1996; Drzik, 2005). In our article, we treat economic capital as a given quantity. The major risk for a nonlife underwriting centre is volatility in claim pattern causing a direct volatility in the fair value. The major risk for the life underwriting centre is that small volatility in a particular year will magnify over a long time horizon. Both effects are adequately captured in the economic capital on a fair value basis (cf. Doff, 2006; IAA, 2004). As a consequence, the relative performance measure is RAROC as the ratio of added underwriting fair value and the economic capital (Zaik et al., 1996; Saita, 1999; Schierenbeck, 2003).

In the second section we indicated that the underwriting performance should be evaluated as the difference between actual and expected underwriting variables. This is also reflected in the fair value of the underwriting centre. There may seem to be an incentive for the underwriting centre to estimate the expected claim costs too high in order for the underwriting centre to increase the fair value profit over the subsequent years. This is in line with current actuarial practice to estimate claim costs prudently and subsequently realize a run-off result. However, misestimation of claim costs results in a too low fair value profit when selling the product. Another potential consequence of misestimation of claim costs is a too high pricing, which is also (commercially) unfavorable for the underwriting centre. Because the funds transfer price is the risk-free rate the underwriting centre does not earn a real return on the prudence margin in the liabilities. Because misestimation is ignored in the performance measure of the underwriting centre the incentive to misestimate the claim costs is neutralized.

The underwriting centre is evaluated on its economic capital only. The book value of equity capital on the balance sheet of that particular legal entity does not play a role in performance evaluation. Hence it is possible for the insurance firm as a whole to manage the available book capital base in an optimal manner, irrespective of where it is located exactly.

\section{The Investment Centre}

The investment centre manages the assets covering the insurance liabilities (mismatch position) and the free assets. Because all assets are fair valued (mark-to-market), the performance measure of the investment centre is added investment fair value. Risk is evaluated by economic capital as the overarching risk limit. Consequently, RAROC is the relative performance measure of the investment centre.

\section{Taking It All Together}

Let us now evaluate whether we have solved the problems as identified in the second section. Fair value is the central performance measure for the funds transfer pricing system in insurance with economic capital as the central risk measure. Fair value and economic capital are evaluated for the underwriting and investment centre separately 
and then aggregated to arrive at total fair value for the entire firm. As a result, both performance and risks are well separated and the funds transfer pricing system provides management with adequate management control information. Problem 1 of the second section is resolved. Both responsibility centers can steer their performance uniquely, that is, without interference of effects beyond their control. This resolves the problem 2 as well.

Problems 3 to 5 are related to goal congruence. These problems have all been resolved by choosing the appropriate transfer price. Alternatives to choose different transfer prices have not been evaluated because the risk-free rate already resolves our problem.

This means that we have also satisfied the criteria we laid out in the beginning of the fourth section because performance and risk are measured uniquely and allocated to the responsibility centre that has the instruments to manage the risk.

One remaining question is: if applying the proposed funds transfer pricing system is such a sensible thing to do, why have insurance companies around the globe not implemented such a system yet? In the second section we concluded that insurance firms' ALM strategy is executed relatively separate from the underwriting business, but that performance measures continued to be integral. In the second section we noted the importance of goal-congruent performance measures. Based on disclosed information by insurance undertakings, we observe an increasing importance of embedded value. We argued in the second section that embedded value as a performance measure also takes into account an integral perspective. Anecdotal evidence shows that some leading insurers are in the process of implementing the funds transfer pricing system in order to resolve the problems highlighted in this article.

\section{A Practical Example ${ }^{2}$}

We investigate the funds transfer pricing system in an example with a traditional life insurance product. It is bought by a 50-year-old client at a premium of $€ 60,000$ at $t=0$. The policy pays a lump sum of $€ 100,000$ at the age of 65 or 90 percent of that amount at death, if earlier. For simplicity, we assume a simplified mortality rate structure: the probability that the policyholder dies at age 64 is 0.25 and the probability that he survives age 65 is 0.75 .

In traditional terms, the embedded value is calculated by discounting future expected cash flows with a 10 percent discount rate because this is based on a long-term average investment return. However, at this moment the government bond yield is 4 percent. For simplicity, we ignore expenses and lapse rates. Therefore, the embedded value is $€ 36,121$, because at $t=0$ the net present value (NPV) of expected benefit payments is $€ 23,879$ (see Table 2). The underwriting manager may (incorrectly!) interpret the embedded value to be a 66 percent profit margin (i.e., $60,000 / 36,121 \times 100$ percent $=166$ percent). Hence, he has an incentive to either decrease premiums or increase benefit payments, for instance, by guaranteed investment returns. When the investment return turns out to be low, this is an incentive to assume additional investment risks to make up the losses.

\footnotetext{
${ }^{2}$ This section is derived from Doff (2006).
} 


\section{TABLE 2}

Performance Evaluation Under the Traditional Embedded Value System

\begin{tabular}{lcc}
\hline Underwriting Centre & $t=0$ & $t=1$ \\
\hline Premium $(=a)$ & $€ 60,000$ & $€ 60,000$ \\
Benefit at alive $(t=15)$ & $€ 100,000$ & $€ 100,000$ \\
NPV $(r=10 \%)$ & $€ 23,939$ & $€ 26,333$ \\
Probability of alive & 0.75 & 0.80 \\
Expected value $(=b)$ & $€ 17,954$ & $€ 21,067$ \\
Benefit at death $(t=14)$ & $€ 90,000$ & $€ 90,000$ \\
NPV $(r=10 \%)$ & $€ 23,700$ & $€ 26,070$ \\
Probability of death & 0.25 & 0.20 \\
Expected value $(=c)$ & $€ 5,925$ & $€ 5,214$ \\
Total expected value $(d=b+c)$ & $€ 23,879$ & $€ 26,280$ \\
Value new business $(t=0)(=a-d)$ & $€ 36,121$ & $€ 2,401$ \\
Embedded value profit $(t=1)$ & & $€ 4,800$ \\
Investment return $(8 \%)$ & & $€ 7,201$ \\
Total performance & $€ 36,121$ & \\
\hline
\end{tabular}

During the first year, two circumstances occur. First, mortality expectations change. The probability of dying at age $64(t=14)$ changes to 0.20 and probability of surviving age $65(t=15)$ is 0.80 . Second, the actual investment return is 8 percent, earned over the invested premium of $€ 60,000$. Hence, the profit of this policy is $€ 7,201$ (see Table 3 ). It is mainly caused by discounting the cash flows 1 year less. The adverse effects, such as the negative developments in mortality and investment returns are hardly visible. As a result, there is no incentive to take measures.

Implementing the funds transfer pricing system separates the underwriting centre from the investment centre. As the government bond rates are 4 percent, this is also the transfer price and hence also the discount rate used in the fair valuation of the insurance liabilities. The fair value of the insurance liabilities is $€ 54,638$ and this is transferred against the risk-free rate to the investment centre. The budgeted underwriting profit is $€ 7,547$ including the benefit on the internal transactions (see Table 3 ). This is a 13.8 percent profit margin $(7,547 / 54,638 \times 100$ percent $=13.8$ percent $)$. The 1 -year budgeted profit of the investment centre is the expected 10 percent investment return over the $€ 60,000$ premium less the costs of the internal transactions.

During the first year, the same two circumstances occur (mortality and interest rates change). Now that the two responsibility centres are separated, the two effects are separately visible (see Table 3 ). The underwriting centre has a profit of $€ 4,556$, which is significantly lower than under the traditional embedded value system. The loss due to the decreasing mortality rate is neutralized by the discounting effect. There is an incentive to manage benefit payments and potentially hedge the risk of further deterioration of mortality rates. 


\section{TABLE 3}

Performance Evaluation Under the Transfer Pricing System

\begin{tabular}{lcclcl}
\hline Underwriting Centre & $t=0$ & $t=1$ & Investment Centre & $t=0$ & $t=1$ \\
\hline Premium $(=a)$ & $€ 60,000$ & $€ 60,000$ & Asset portfolio & $€ 60,000$ & $€ 60,000$ \\
& & & Investment return (10\%) & $€ 6,000$ & \\
Benefit at alive $(t=15)$ & $€ 100,000$ & $€ 100,000$ & Investment return (8\%) & & $€ 4,800$ \\
NPV $\left(r_{f}=4 \%\right)$ & $€ 55,526$ & $€ 57,748$ & & & \\
Probability of alive & 0.75 & 0.80 & Replicating portfolio & $€ 54,638$ & $€ 54,638$ \\
Fair value $(=b)$ & $€ 41,645$ & $€ 46,198$ & Paid transfer price $(4 \%)$ & $€ 2,186$ & $€ 2,186$ \\
Benefit at death $(t=14)$ & $€ 90,000$ & $€ 90,000$ & Fair value profit & $€ 3,814$ & $€ 2,614$ \\
NPV $\left(r_{f}=4 \%\right)$ & $€ 51,973$ & $€ 54,052$ & & & \\
Probability of death & 0.25 & 0.20 & & & \\
Fair value $(=c)$ & $€ 12,993$ & $€ 10,810$ & & & \\
& & & & & \\
Total fair value $(d=b+c)$ & $€ 54,638$ & $€ 57,008$ & & & \\
Earned fair value $(=a-d)$ & $€ 5,362$ & $€ 2,370$ & & & \\
Received transfer price & $€ 2,186$ & $€ 2,186$ & & & \\
Fair value profit & $€ 7,547$ & $€ 4,556$ & & & \\
Total performance of the two responsibility centres & & & \\
\hline
\end{tabular}

\section{TABLE 4}

Summary of Incentives in the Example

\begin{tabular}{lll}
\hline Performance Measure & $t=1$ & \multicolumn{1}{c}{ Incentive } \\
\hline $\begin{array}{l}\text { Traditional performance measures } \\
\text { Embedded value profit }\end{array}$ & $€ 7,201$ & $\begin{array}{l}\text { Decrease premiums } \\
\text { Provide investment guarantees }\end{array}$ \\
$\begin{array}{l}\text { Funds transfer pricing system } \\
\text { Underwriting centre }\end{array}$ & $€ 4,556$ & $\begin{array}{l}\text { Manage claim benefits } \\
\text { Hedge mortality risk }\end{array}$ \\
$\begin{array}{l}\text { Investment centre } \\
\text { Total profit }\end{array}$ & $€ 2,614$ & Take balanced asset risk \\
\hline
\end{tabular}

The investment centre gains a profit of $€ 2,614$ by investing the premium against 8 percent (which is lower than the budgeted 10 percent) funded by the internal transactions. Hence, the investment centre still makes a profit, but less than expected. There is an incentive to improve the returns, for instance, by assuming a balanced investment risk. The investment centre can optimize its investment strategy by trading off risk and return.

At $t=1$ the sum of underwriting and investment centre is $€ 7,170$, which is $€ 31$ lower than in the traditional calculation (Table 4). This is because the 10 percent discounted 
budgeted investment returns are already taken at inception, that is, before they are realized.

\section{CONCLUSION}

The current practice of ALM in insurance firms fails to satisfy conditions for effective control and fails to reflect goal congruence. This causes management control problems so that managers are unable to run their business effectively. This could result in unintended risks for the insurance firm as a whole. We showed that the funds transfer pricing system, a well-established system within banks, can be implemented in insurance.

We argued that implementing the funds transfer pricing system in insurance promotes goal-congruent behavior and resolves the management control problems. It requires identifying two separate responsibility centers: the underwriting and investment centres. The underwriting centre matches its insurance liabilities through internal transactions with the investment centre. As a result, the investment risks are uniquely allocated to the investment centre. Hence, applying the proposed transfer pricing system in insurance companies satisfies the conditions for effective management control as also highlighted in the simple although practical example.

\section{References}

Aalst Van Der, P. C., 1995, Risico-analyse en Matching bij Pensioenfondsen, Ph.D. thesis, Erasmus University.

Allen, F., and A. M. Santomero, 1999, What Do Financial Intermediaries Do? Journal of Banking and Finance, 25: 271-294.

AMIfs Research Committee, 2001, Assignment of Contribution for Funds Transferred Internally, Journal of Bank Cost and Management Accounting, 14(3): 12-24.

Anthony, R. N., 1988, The Management Control Function (Cambridge, MA: Harvard Business School Press).

Anthony, R. N., J. Dearden, and V. Govindarajan, 1992, Management Control Systems, 7th edition (Homewood, IL: Irwin).

Anthony, R. N., and V. Govindarajan, 2003, Management Control Systems, 11th edition (New York: McGraw-Hill).

Babbel, D. F., J. Gold, and C. B. Merrill, 2002, Fair Value of Liabilities: The Financial Economics Perspective, North American Actuarial Journal, 6(1): 12-27.

Booth, P., R. G. Chadburn, D. R. Cooper, S. Haberman, and D. E. James, 1999, Modern Actuarial Theory and Practice (Boca Raton, FL: Chapman \& Hall).

Broadie, M., J. Cvitanic, and H. M. Soner, 1998, Optimal Replication of Contingent Claims Under Portfolio Constraints, Review of Financial Studies, 11: 59-79.

Calandro, J., and S. Lane, 2004, Why the Property and Casualty Insurance Industry Needs a New Performance Measure, Measuring Business Excellence, 8(2): 31-39.

Chittenden, J., 2000, A Bank's Focal Point for Market Risk: The Transfer Pricing Mismatch Unit, Journal of Bank Cost and Management Accounting, 13(1): 3-23.

Comité Européen des Assurances, 2006, CEA Document on Cost of Capital, April 21. 
Comité Européen des Assurances, 2007, Results and Discussion on the Impact Assessment of the Future Solvency II Framework on Insurance Products and Markets, March 2007.

de Leeuw, A. C. J., 1990, Organisaties: Management, Analyse, Ontwerp en Verandering: een Systeemvisie, 4th edition (Assen: Van Gorcum).

Doff, R. R., 2006, Risk Management for Insurance Firms: A Framework for Fair Value and Economic Capital, Ph.D. thesis, Twente University.

Doff, R. R., 2007, Risk Management for Insurers: Risk Control, Economic Capital and Solvency II (London: Risk Books).

Drzik, J., 2005, At the Crossroads of Change: Risk and Capital Management in the Insurance Industry, Geneva Papers, 30: 72-87.

Federal Office of Private Insurance, 2006, The Swiss Experiences With Market-Consistent Technical Provisions-The Cost of Capital Approach, February 24, 2006.

Gorton, G., and A. Winton, 2002, Financial Intermediation, Wharton Working Paper 02-28.

Harris, M., and A. Raviv, 2005, Allocation of Decision-Making Authority, Review of Finance, 9(3): 353-383.

International Actuarial Association, 2004, A Global Framework for Insurer Solvency Assessment.

International Actuarial Association, 2007, Measurement of Liabilities for Insurance Contracts: Current Estimates and Risk Margins, Exposure Draft February 23, 2007.

Kafafian, R. E., 2001, Keys to Community Bank Success: Utilizing Management Information to Make Informed Decisions, Journal of Bank Cost and Management Accounting, 14(1): 16-28.

Kimball, R. C., 1997, Innovations in Performance Measurement in Banking, New England Economic Review, May/June: 23-38.

Klumpes, P. J. M., 2005, Managerial Use of Discounted Cash-Flow or Accounting Performance Measures: Evidence From the U.K. Life Insurance Industry, Geneva Papers on Risk and Insurance, 30: 171-186.

KPMG, 2002, Study into the Methodologies to Assess the Overall Financial Position of an Insurance Undertaking from the Perspective of the Prudential Supervisor, May 2002.

Liebenberg, A. P., and R. E. Hoyt, 2003, The Determinants of Enterprise Risk Management: Evidence From the Appointment of Chief Risk Officers, Risk Management and Insurance Review, 6(1): 37-52.

Mercer Oliver Wyman, 2004, Life at the End of the Tunnel? The Capital Crisis in the European Life Sector, February 2004.

Pape, J. C., 1999, Commercial Lending in Different Governance Sytems, Ph.D. thesis, Twente University.

Payant, W.R., 2000, Funds Transfer Pricing and A/L Modelling, Journal of Bank Cost and Management Accounting, 13(3): 67-75.

Rubinstein, M., 2001, Derivatives Performance Attribution, Journal of Financial and Quantitative Analysis, 36(1): 75-92.

Santomero, A. M, and D. F. Babbel, 1997, Financial Risk Management by Insurers: An Analysis of the Process, Journal of Risk and Insurance, 64(2): 231-270. 
Saita, F., 1999, Allocation of Risk Capital in Financial Institutions, Financial Management, 28(3): 95-111.

Schierenbeck, H., 2003, Ertragsorientiertes Bankmanagement. Band 1: Grundlagen, Marktzinsmethode und Rentabilitäts-Controlling, 8th edition (Wiesbaden: Gabler).

Smink, M., 1995, Asset-Liability Management in Life Insurance: Towards a Theory of Liability Driven Investment Management, Ph.D. thesis, Groningen University.

Zaik, E., E. J. Walter, G. Kelling, and C. James, 1996, RAROC at Bank of America: From Theory to Practice, Journal of Applied Corporate Finance, 1996, 9(2): 83-92. 